\title{
Environmental Issues in Supply Chain Management using MCDM Tool - An Example from Mining Industry
}

\author{
M.Ramaganesh, S.Bathrinath, S.Devendran, T.Hariharan, A.Hariharan
}

\begin{abstract}
Green supply chain management is being concerned for both development and eminent difficulties are observed through supply chain mining activities. In Mining Industry, All the exercises engaged with extraction, generation, circulation add to ecological concerns. The ecological and health problem are still now prevailing due to uncaring in green supply chain activities. In our thesis the environmental problems are categorized as main factors and sub factors by collecting opinion from industrial experts \& reputed literature survey. The main factors and sub-factors are rated and evaluated by one of the multi criteria decision making tool (MCDM) i.e Fuzzy Analytic Network Process (ANP). According to AHP, the main factors and sub factors are rated and arranged as more affecting factor to environment based on global value attained. As the result, it was found that the most influencing factors are Impact on land and its sub factors.
\end{abstract}

Keywords: Analytic Network Process, Environmental Issues, Health issues, Mining Industry, Supply Chain Management.

\section{INTRODUCTION}

G reen supply chain practice and their role in the mining industries is important so that the raw material is converted into desired product. The process which are followed to convert the material are highly supervised by the management to decrease the environmental issues. The main contribution of the mining industry is to produce product with less or no effect to the environment. A country's growth is based on the production of the valuable products. The valuable product is manufactured in the mining industry with the help of mines and ores. As we know that a coin as two sides, many new products are manufactured which is helpful

Revised Manuscript Received on December 05, 2019.

* Correspondence Author

M.Ramaganesh, Department of Mechanical Engineering, Kalasalingam Academy of Research and Education, Krishnankoil, India, Email: ramaganesh87@gmail.com

S.Bathrinath*, Department of Mechanical Engineering, Kalasalingam Academy of Research and Education, Krishnankoil, India. Email: bathri@gmail.com

S.Devendran, Department of Mechanical Engineering, Kalasalingam Academy of Research and Education, Krishnankoil, India.

Email:devendran.s1997@gmail.com

T.Hariharan, Department of Mechanical Engineering, Kalasalingam Academy of Research and Education, Krishnankoil, India.

Email:hariharan131997@gmail.com

A.Hariharan, Department of Mechanical Engineering, Kalasalingam Academy of Research and Education, Krishnankoil, India.

Email:hariharannells02@gmail.com for society but at the same time many environmental issues are created. The mining activities have bought massive degradation to environment, depletion of natural resources and create a barrier to further development of the industry and society. The mining activities include such as digging or explosives using chemicals are done. Due to explosives the environment is drastically get disturbed in following manners like soil erosion, earthquake, the water and land habitat are get affected. At the same time, the chemicals are released during explosive stage, so that the water is getting contaminated and polluted. Automatically the quality of water is reduced and it becomes contaminant water and also the ground water level is getting reduced day by day. During leaching process, the toxic chemical cyanide is involved so the cyanide is released into water. In mining industry, after extraction of the minerals the materials are transported for further process. While transport greenhouse gases are released such as nitrates, carbon dioxide etc. and also, dust is produced. It results in many problems to humans such as skin diseases, breathing problem, irritation to eyes etc.... now a days mining industry must manufacture the product with acceptable government norms and creating less pollution to environment.

\section{LITERATURE REVIEW}

Heledd et.al. [1] explores recent trends in the reporting of impact in the global mining industries and detailed review of the development of social and environmental disclosure and analysis of the recent trends in disclosure using a case study world's 10 largest mining industries. Simonov et.al. [2] analyzed the green supply chain practices are followed in mining industries to reduce the rate of environmental issues. The environmental issues considered are soil erosion, earthquake and chemical explosive. Those issues are evaluated and rated by using fuzzy TOPSIS methodology. They suggested that other weighing techniques such as Analytical hierarchy process (AHP) can be used for making comparisons. Marcos et.al. [3] made the comparison of the environmental issues among different nations rather than single coal mining industry. The coal fires in the mining industry are studied using advanced electron beam and x-ray diffraction technique. The mineral constitution in the coal fire are calcite, gypsum, quartz and also small quantity of Sulphur, pyrite, magnate and chlorite, dolomite also detected. The soil sample from coal drainage is tested for particle size using Nikon SMZ645 dividing optical microscope. They found the results as the emission of $\mathrm{CO} 2, \mathrm{CO}, \mathrm{CH} 4, \mathrm{C} 4 \mathrm{H} 10$, and $\mathrm{C} 6 \mathrm{H6}$ varies for different month which affect the environment as well as

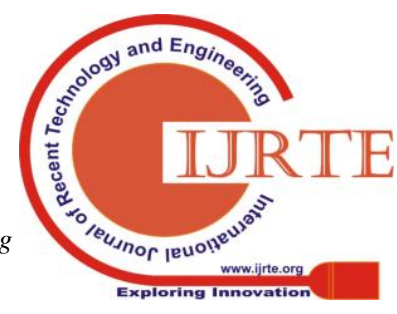


human health in the mining industry area. Bian et.al. [5] proposed a two-way method to reconstruct the farmer's house in china and also introduced a methodology to solve environmental problems. Coal production in china is increased accordingly by the reduction of number of coal mines to around $50 \%$. Some of the reclamation activities followed by mining industry to reduce environmental effect is reconstruction of rural commodities, native residential improvement etc. discussed the environmental issues related to coal mine accidents, land subsidence, emission of gases etc.... The major emission of the industry is methane. At the same time methane is used for electricity generation and industrial purpose. To reduce the environmental issues the waste, need to be reused as fuel for power generation and making of bricks etc. the land which involved for coal mining are need to be involve for land recreation, agriculture purpose etc. Tiwary [6] suggested a two-tier management system to minimize the impact of mine waste water to the surroundings. Initial level management suggests that while considering the land usage, ground water flow for the selection of the dumping sites to avoid impact on ground and surface water quality. Secondary level management suggests that the protectionary measures taken to minimize the soil erosion, acid mine drainage, etc. Sloss [7] explained briefly about the corporate social responsibility on mining industry. The factors which are all get affected are land, water etc. The factors that cause the degradation are greenhouse gas, truck and mine site machinery, dust and transport are explained along with many case studies. Various technique to control the waste, the company standards, and major coal exporting countries are described. Ayag et.al. [8] used fuzzy analytic network process (ANP) to select the machine tool. For selecting the machine tool, they focused on improving the customer satisfaction and increased profitability as main factors. They considered 25 sub factors like spindle speed, main power, tool change time, specialized training etc. These factors are analyzed using fuzzy analytic network process (ANP). They suggested that in future, a knowledge-based system or expert system can be adopted to interpret the analysis results. Cengiz et.al. [9] used ANP for QFD planning process for a PVC window and door system producing company. They proposed a Fuzzy optimization model to determine the product technical requirements stage in the QFD process. Fuzzy ANP model was used to determine the coefficients of the objective function. They insisted that future research, different AHP approaches and fuzzy optimization models may be used to compare the results. Jafar et.al. [10] developed a Fuzzy ANP model to evaluate the potential suppliers and select the best supplier based on by considering vendor important factors. They also used fuzzy set theory to cover the indeterminacy of decisions made. The supplier criteria considered are supplier's qualitative capability, supplier's delivery capability, supplier financial status and supplier performance antecedents etc.... These criteria are compared by pair wise comparison and then rated as per scoring scale. As a result, global value denotes the important criteria for development. From the comparison matrix, nonlinear programming model was developed and validated by taking numerical samples

\section{PROBLEM FORMULATION}

In the mining industries, the waste is generated due to various process like explosive, coal fire, transportation etc... this waste is emitted and affecting the environment. The main factors and sub factors are selected by using many literature reviews and also collected opinion from mining industry experts. The main factors and sub factors are furnished in table I.

Table I. List of factors affect the environment

\begin{tabular}{|c|c|c|c|}
\hline $\begin{array}{l}S . \\
\text { no }\end{array}$ & Main factor and sub factors & $\begin{array}{l}\text { Notatio } \\
n\end{array}$ & Reference \\
\hline \multirow[t]{5}{*}{1} & Influence on land & IOL & (25) \\
\hline & a) Area of top soil & $\mathrm{AT}$ & (13) \\
\hline & b) Plants and wildlife & PW & $(3,5,1)$ \\
\hline & c) Roads and residence & $\mathrm{RR}$ & (1) \\
\hline & d) Earthquake & EQ & $(5,1)$ \\
\hline \multirow[t]{6}{*}{2} & Influence on water & IOW & (11) \\
\hline & Chemical explosive & $\mathrm{CE}$ & $(5,10)$ \\
\hline & Acid mine drainage & AMD & $(3,9,12)$ \\
\hline & Change in ground level & CGL & (13) \\
\hline & Water habitat & WH & $(9,5,1)$ \\
\hline & Nitrates release into water & NRW & $(10)$ \\
\hline \multirow[t]{5}{*}{3} & Influence of gases & $I G$ & (8) \\
\hline & Greenhouse gases & GG & $(8,6)$ \\
\hline & Coal bed methane & CBM & (6) \\
\hline & Seam gas & SG & (4) \\
\hline & Methane in fugitive manner & MFM & (6) \\
\hline \multirow[t]{4}{*}{4} & Influence of dust & $I D$ & (8) \\
\hline & Hauling \& blasting & $\mathrm{H} \& \mathrm{~B}$ & (7) \\
\hline & Aesthetic damage & $\mathrm{AD}$ & (2) \\
\hline & Breathing \& cough & $\mathrm{BC}$ & $(2,9)$ \\
\hline \multirow[t]{5}{*}{5} & Trucks and equipment & $T E$ & (24) \\
\hline & $\mathrm{NO}_{\mathrm{x}}$ emission & NOx & (8) \\
\hline & High cost & $\mathrm{HC}$ & (10) \\
\hline & Unavoidable dust & UD & $(9,8)$ \\
\hline & Noise level & NL & $(9,10)$ \\
\hline
\end{tabular}

\section{A. Influence on land}

Area of top soil: Mining action will leads to destruction of top soil and landscape. There can be a progressively perpetual impact on the scene from peak mining or at mines in developing economies with increasingly loosened up ways to deal with recovery. Soil profile are get collapsed.

Plants and wildlife: The land or soil dependent plants and wildlife are get affected due to landscape. In some cases the plants and wildlife are lost their life.

Roads and residence: Due to mining process, the landscape occur which simultaneously leads to block or damages of roads and residence.

Earthquake: Extreme digging and blasting of land will automatically leads to earthquake. Earthquake is nothing but collapse of entire area which affect the human life and nature.

\section{B. Influence on water}

Chemical explosive: The blasting process involve chemicals like TNT (trinitrotoluene), ammonium nitrate etc. this chemicals affect the nature of water and future not suitable for usage.

Acid mine drainage: AMD is a major risk factor that affect the water resources, plants and wildlife, fish etc... the metal such as gold, silver, copper are found in the rock along with the sulfide mineral. The

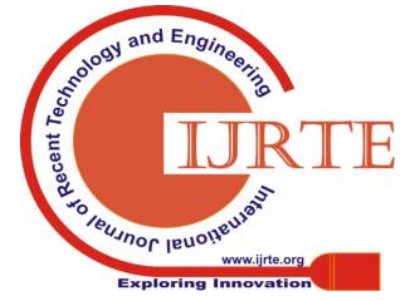


sulphuric acid are formed when the sulfide minerals are exposed to air and water. The mining industry discharge the acid mine waste to the water. So the local availability water are get polluted.

Change in ground level: The level of water in underground is drastically changed when the mining waste mix with water. This mine waste reach the ground level through the fracture or crack due to drilling.

Water habitat: when the water get polluted, automatically the aquatic organisms like fishes, insects, and birds are affected. Nitrates release into water: Through explosive process, up to $28 \%$ of the nitrates from ammonium nitrate fuel oil explosives can finish up draining into the water in an underground mine as the unstable materials are stored around the impact site and wind up washed into the run-off territories site.

\section{Influence of gases}

Greenhouse gases: Greenhouse gases such as methane(CH4), nitrous oxide(N2O), carbon monoxide(CO), Sulphur dioxide(SO2), ozone(O3) etc.. are released during combustion of fossil fuel, production and transport of fuel etc. these greenhouse gases affect the environment and human health also.

Coal bed methane: CBM comprise $\mathrm{CO} 2, \mathrm{H} 2, \mathrm{~N} 2, \mathrm{C} 2 \mathrm{H} 2, \mathrm{H} 3$ are formed during coal formation. This are present on the surface of the coal. During mining process, the coal bed methane is released into atmosphere.

Seam gas: SG contain $\mathrm{CH} 4, \mathrm{CO} 2, \mathrm{~N} 2$, ethane trace are released during mining activities which causes environmental destruction like contamination of water, damages to vegetation, flora and fauna, land etc..

Methane in fugitive manner: Methane is a poisonous gas among the greenhouse gas which is very harmful to both human and environment. Methane are released during sea fuel transport, underground mining etc. Methane is 21 times more potent in its greenhouse effect than $\mathrm{CO} 2$.

\section{D.Influence of dust:}

Hauling \& blasting: $\mathrm{H} \& \mathrm{~B}$ is the basic process to reduce the size of the rock. The blasting process involve the chemical compound like ammonium nitrate/fuel oil mixture. This leads to leaching of chemicals into water and get polluted or contaminated. The formation of dust is also a major issues to environment and human health.

Aesthetic damage: due to breath of greenhouse gases which is emitted from mining activities like coal burn, transport of coal, blasting causes damages to health such as physical injury, aesthetic damage, muscular skeleton disorder.

Breathing \& cough: The size of the dust particle varies from 10-100 microns in diameter. This particles enter into nose, throat, upper respiratory tract and cause cough \& breathing problem.

\section{E. Trucks and equipment}

NOx emission: NOx is a dangerous pollutant that is maximum released from mining activities like drilling process, chemical explosives, transport of coal, mine fires, coal burning etc.. This causes damages to health and environment.

High cost (transport): The mode of coal transport in mining industry is trucks, rails, ship etc... The cost invested for coal transport is high and the maintenance cost is also high. The cost also vary depend on the quantity of transport utilized.

Unavoidable dust: Dust particles are emitted by coal and soil to atmosphere while mining process. The dust is also released by drilling, blasting and processing of coal process etc... The dust emitted to environment cause health issues.

Noise level: The noise level occurs between 80-1040 db. Heavy noise created by haulage, gear, ventilators, fans, cutting and drilling machines. Hearing damage occurs to workers who works up to $8 \mathrm{hrs}$ and above the noise level of $90 \mathrm{db}$. The machines should be properly maintained for proper working condition.

\section{METHODOLOGY}

In the mining industry, the wastes are generated due to careless monitoring of the activities like production, manufacturing, packing etc.., many factors that affecting the environment are described in our paper. The factors like water, land, gas, dust etc.., among this factor which is more dangerous is discussed using one of multi criteria decision making tool (MCDM tool). The tool which is utilized in our paper is Fuzzy analytical network process (ANP).

In the AHP, each element in the hierarchy is considered to be independent of all the others - the decision criteria are considered to be independent of one another, and the alternatives are considered to be independent of the decision criteria and of each other. But in many real-world cases, there is interdependence among the items and the alternatives. ANP does not require independence among elements, so it can be used as an effective tool in these cases. Both the AHP and ANP would provide useful frameworks to use in making his decision. In reality, a holistic approach like analytic network process (ANP), a more general form of AHP is needed if all attributes and alternatives involved are connected in a network system that accepts various dependencies. Saaty (1981) was a person who introduced the analytical network process (ANP) methodology. Truly, an all-encompassing methodology like expository system process (ANP), an increasingly broad type of AHP is required if all qualities and options included are associated in a system framework that acknowledges different conditions. The procedure for the ANP is as follows.

Step 1: The main factors and sub factors are detected for analyzing process.

Step 2: The ANP demonstrate are structured progressively.

Step 3: Using pairwise comparison matrix, the local weights are determined for main factors and sub factors with the help of fuzzy scale.

Step 4: The inner dependence matrix can be determined by using fuzzy scale for each factor depending on other factor. From the step 3, the product of inner dependence and local weight factors can be used to find the inter dependence weight factor as given in step 3 .

Step 5: Global weights for sub factors are predicted by the product of interdependent weight of the factor and local weight of the sub factor.

The main factors and sub factors are rated and interrelationship is made among the sub factors with the help of linguistic fuzzy scale table II.

Table II: linguistic scale factor for importance and difficulty.

\begin{tabular}{|l|l|l|l|}
\hline $\begin{array}{l}\text { Linguistic scale } \\
\text { for difficulty }\end{array}$ & $\begin{array}{l}\text { Linguistic scale } \\
\text { for importance }\end{array}$ & $\begin{array}{l}\text { Triangular } \\
\text { fuzzy scale }\end{array}$ & $\begin{array}{l}\text { Triangular } \\
\text { fuzzy reciprocal } \\
\text { scale }\end{array}$ \\
\hline Just equal & Just equal & $(1,1,1)$ & $(1,1,1)$ \\
\hline
\end{tabular}




\begin{tabular}{|l|l|l|l|}
\hline $\begin{array}{l}\text { Equally difficult } \\
\text { (ED) }\end{array}$ & $\begin{array}{l}\text { Equally } \\
\text { important (EI) }\end{array}$ & $(1 / 2,1,3 / 2)$ & $(2 / 3,1,2)$ \\
\hline $\begin{array}{l}\text { Weakly more } \\
\text { difficult } \\
\text { (WMD) }\end{array}$ & $\begin{array}{l}\text { Weakly more } \\
\text { important } \\
\text { (WMI) }\end{array}$ & $(1,3 / 2,2)$ & $(1 / 2,2 / 3,1)$ \\
\hline $\begin{array}{l}\text { Strongly more } \\
\text { difficult (SMD) }\end{array}$ & $\begin{array}{l}\text { Strongly more } \\
\text { important (SMI) }\end{array}$ & $(3 / 2,2,5 / 2)$ & $(2 / 5,1 / 2,2 / 3)$ \\
\hline $\begin{array}{l}\text { Very strongly } \\
\text { more difficult } \\
\text { (VSMD) }\end{array}$ & $\begin{array}{l}\text { Very strongly } \\
\text { more important } \\
\text { (VSMI) }\end{array}$ & $(2,5 / 2,3)$ & $(1 / 3,2 / 5,1 / 2)$ \\
\hline
\end{tabular}

\section{RESULTS AND DISCUSSIONS}

The pairwise comparison for the main factors and sub factors is done with the help of linguistic scale given in the table. The comparison is made by the way of query, in what manner "influence on land is so important to influence on water" the reply is given based on (or) related to linguistic scale along with triangular fuzzy scale given in table. By this way, the comparison is completed for all other main factors and sub factors. Along with that local weight is also calculated.

A. Sample Calculation:

Influence on land is compared with influence on water, the selected option is "equally important" based on linguistic scale. Then the influence on water is compared with influences of gases, dust and truck and equipment. The fuzzy number given to main factors as follows:

IOL compare with $\mathrm{IOW}=(1 / 2,1,3 / 2)$

IOW compare with $\mathrm{IOW}=(1,1,1)$

IG compare with $\mathrm{IOW}=(1 / 3,2 / 5,1 / 2)$

ID compare with $\mathrm{IOW}=(2 / 5,1 / 2,2 / 3)$

TE compare with IOW $=(2 / 7,1 / 3,2 / 5)$.

Table III Local weight and pairwise comparison of main factors

\begin{tabular}{|c|c|c|c|c|c|c|c|c|c|c|c|c|c|}
\hline & AT & AT & AT & PW & PW & PW & RR & RR & RR & EQ & EQ & EQ & \\
\hline AT & 1 & 1 & 1 & 0.5 & 1 & 1.5 & 1 & 1.5 & 2 & 1 & 1.5 & 2 & \\
\hline PW & 0.66667 & 1 & 2 & 1 & 1 & 1 & 0.5 & 1 & 1.5 & 1 & 1.5 & 2 & \\
\hline RR & 0.5 & 0.66667 & 1 & 0.66667 & 1 & 2 & 1 & 1 & 1 & 1 & 1.5 & 2 & \\
\hline EQ & 0.5 & 0.66667 & 1 & 0.5 & 0.66667 & 1 & 0.5 & 0.66667 & 1 & 1 & 1 & 1 & \\
\hline \multirow[t]{3}{*}{ SUM } & 2.66667 & 3.33333 & 5 & 2.66667 & 3.66667 & 5.5 & 3 & 4.16667 & 5.5 & 4 & 5.5 & 7 & \\
\hline & & & & & & & & & & & & & local \\
\hline & & & & & & & & & & & & & weight \\
\hline \multirow[t]{4}{*}{ AVG } & 0.375 & 0.3 & 0.2 & 0.1875 & 0.27273 & 0.27273 & 0.33333 & 0.36 & 0.36364 & 0.25 & 0.27273 & 0.28571 & 0.28945 \\
\hline & 0.25 & 0.3 & 0.4 & 0.375 & 0.27273 & 0.18182 & 0.16667 & 0.24 & 0.27273 & 0.25 & 0.27273 & 0.28571 & 0.27228 \\
\hline & 0.1875 & 0.2 & 0.2 & 0.25 & 0.27273 & 0.36364 & 0.33333 & 0.24 & 0.18182 & 0.25 & 0.27273 & 0.28571 & 0.25312 \\
\hline & 0.1875 & 0.2 & 0.2 & 0.1875 & 0.18182 & 0.18182 & 0.16667 & 0.16 & 0.18182 & 0.25 & 0.18182 & 0.14286 & 0.18515 \\
\hline
\end{tabular}

The values are added in vertical manner. Then the sum values are divided with factors values individually. The average value is calculated for all main factors by above said way. Finally, the local weight is calculated by sum of the average values in horizontal way is divided with total number

of values.

$(0.34426+0.27273+0.17241+0.19849+0.30928+0.36885$ $+0.39063+0.3913+0.38182+0.11667+0.17143+0.2027+0.2$ $5+0.25+0.25) / 15=0.27137$.

Table IV: Local weight and pairwise comparison of IOL sub factors

\begin{tabular}{|c|c|c|c|c|c|c|c|c|c|c|c|c|c|}
\hline & AT & AT & AT & PW & PW & PW & RR & RR & RR & EQ & EQ & EQ & \\
\hline AT & 1 & 1 & 1 & 0.5 & 1 & 1.5 & 1 & 1.5 & 2 & 1 & 1.5 & 2 & \\
\hline PW & 0.66667 & 1 & 2 & 1 & 1 & 1 & 0.5 & 1 & 1.5 & 1 & 1.5 & 2 & \\
\hline RR & 0.5 & 0.66667 & 1 & 0.66667 & 1 & 2 & 1 & 1 & 1 & 1 & 1.5 & 2 & \\
\hline EQ & 0.5 & 0.66667 & 1 & 0.5 & 0.66667 & 1 & 0.5 & 0.66667 & 1 & 1 & 1 & 1 & \\
\hline \multirow[t]{3}{*}{ SUM } & 2.66667 & 3.33333 & 5 & 2.66667 & 3.66667 & 5.5 & 3 & 4.16667 & 5.5 & 4 & 5.5 & 7 & \\
\hline & & & & & & & & & & & & & local \\
\hline & & & & & & & & & & & & & weight \\
\hline \multirow[t]{4}{*}{ AVG } & 0.375 & 0.3 & 0.2 & 0.1875 & 0.27273 & 0.27273 & 0.33333 & 0.36 & 0.36364 & 0.25 & 0.27273 & 0.28571 & 0.28945 \\
\hline & 0.25 & 0.3 & 0.4 & 0.375 & 0.27273 & 0.18182 & 0.16667 & 0.24 & 0.27273 & 0.25 & 0.27273 & 0.28571 & 0.27228 \\
\hline & 0.1875 & 0.2 & 0.2 & 0.25 & 0.27273 & 0.36364 & 0.33333 & 0.24 & 0.18182 & 0.25 & 0.27273 & 0.28571 & 0.25312 \\
\hline & 0.1875 & 0.2 & 0.2 & 0.1875 & 0.18182 & 0.18182 & 0.16667 & 0.16 & 0.18182 & 0.25 & 0.18182 & 0.14286 & 0.18515 \\
\hline
\end{tabular}

Table V: Local weight and pairwise comparison of ID sub factors

\begin{tabular}{|c|c|c|c|c|c|c|c|c|c|c|}
\hline & $H \& B$ & $H \& B$ & $H \& B$ & $A D$ & $A D$ & $A D$ & $\mathrm{~B} \& \mathrm{C}$ & $\mathrm{B} \& \mathrm{C}$ & $\mathrm{B} \& \mathrm{C}$ & \\
\hline$H \& B$ & 1 & 1 & 1 & 1 & 1.5 & 2 & 0.5 & 1 & 1.5 & \\
\hline $\mathrm{AD}$ & 0.5 & 0.66667 & 1 & 1 & 1 & 1 & 1.5 & 2 & 2.5 & \\
\hline $\mathrm{B} \& \mathrm{C}$ & 0.66667 & 1 & 2 & 0.4 & 0.5 & 0.66667 & 1 & 1 & 1 & \\
\hline \multirow[t]{3}{*}{ SUM } & 2.16667 & 2.66667 & 4 & 2.4 & 3 & 3.66667 & 3 & 4 & 5 & \\
\hline & & & & & & & & & & local \\
\hline & & & & & & & & & & weight \\
\hline \multirow[t]{3}{*}{ AVG } & 0.46154 & 0.375 & 0.25 & 0.41667 & 0.5 & 0.54545 & 0.16667 & 0.25 & 0.3 & 0.36281 \\
\hline & 0.23077 & 0.25 & 0.25 & 0.41667 & 0.33333 & 0.27273 & 0.5 & 0.5 & 0.5 & 0.3615 \\
\hline & 0.30769 & 0.375 & 0.5 & 0.16667 & 0.16667 & 0.18182 & 0.33333 & 0.25 & 0.2 & 0.27569 \\
\hline
\end{tabular}


The above method is executed in other sub factors to calculate the local values. The inner dependence weights are calculated by the product of inner dependence and local weight factors. The inner dependence matrix can be determined by using fuzzy scale for each factor depending on other factor. The pairwise comparison is completed by query, that "what is the relative importance of 'influence on water' when compared with 'trucks and equipment' on controlling 'influence on land' the outcome is "very strongly more important" $(2,5 / 2,3)$.

Table VI: Inner dependence matrix of sub factor with respect to IOL

\begin{tabular}{|c|c|c|c|c|c|c|c|c|c|c|c|c|c|}
\hline IOL & IOW & IOW & IOW & IG & IG & IG & ID & ID & ID & TE & TE & TE & \\
\hline IOW & 1 & 1 & 1 & 0.5 & 1 & 1.5 & 1.5 & 2 & 2.5 & 2 & 2.5 & 3 & \\
\hline IG & 0.66667 & 1 & 2 & 1 & 1 & 1 & 1.5 & 2 & 2.5 & 2.5 & 3 & 3.5 & \\
\hline ID & 0.4 & 0.5 & 0.66667 & 0.4 & 0.5 & 0.66667 & 1 & 1 & 1 & 2 & 2.5 & 3 & \\
\hline \multirow[t]{2}{*}{ TE } & 0.33333 & 0.4 & 0.5 & 0.28571 & 0.33333 & 0.4 & 0.33333 & 0.4 & 0.5 & 1 & 1 & 1 & \\
\hline & & & & & & & & & & & & & \\
\hline \multirow[t]{2}{*}{ SUM } & 2.4 & 2.9 & 4.16667 & 2.18571 & 2.83333 & 3.56667 & 4.33333 & 5.4 & 6.5 & 7.5 & 9 & 10.5 & local \\
\hline & & & & & & & & & & & & & weight \\
\hline \multirow[t]{4}{*}{ AVG } & 0.41667 & 0.34483 & 0.24 & 0.22876 & 0.35294 & 0.42056 & 0.34615 & 0.37037 & 0.38462 & 0.26667 & 0.27778 & 0.28571 & 0.32792 \\
\hline & 0.27778 & 0.34483 & 0.48 & 0.45752 & 0.35294 & 0.28037 & 0.34615 & 0.37037 & 0.38462 & 0.33333 & 0.33333 & 0.33333 & 0.35788 \\
\hline & 0.16667 & 0.17241 & 0.16 & 0.18301 & 0.17647 & 0.18692 & 0.23077 & 0.18519 & 0.15385 & 0.26667 & 0.27778 & 0.28571 & 0.20379 \\
\hline & 0.13889 & 0.13793 & 0.12 & 0.13072 & 0.11765 & 0.11215 & 0.07692 & 0.07407 & 0.07692 & 0.13333 & 0.11111 & 0.09524 & 0.11041 \\
\hline
\end{tabular}

Table VII: Inner dependence matrix of sub factors with respect to IOW

\begin{tabular}{|l|r|r|r|r|r|r|r|r|r|r|r|r|r|r|r|}
\hline IOW & IOL & IOL & IOL & IG & IG & IG & ID & ID & ID & TE & TE & TE \\
\hline IOL & 1 & 1 & 1 & 0.5 & 1 & 1.5 & 2 & 2.5 & 3 & 2.5 & 3 & 3.5 \\
\hline IG & 0.66667 & 1 & 2 & 1 & 1 & 1 & 0.5 & 1 & 1.5 & 1.5 & 2 & 2.5 \\
\hline ID & 0.33333 & 0.4 & 0.5 & 0.66667 & 1 & 2 & 1 & 1 & 1 & 0.5 & 1 & 1.5 \\
\hline TE & 0.28571 & 0.33333 & 0.4 & 0.4 & 0.5 & 0.66667 & 0.66667 & 1 & 2 & 1 & 1 & \\
\hline
\end{tabular}

\begin{tabular}{|c|c|c|c|c|c|c|c|c|c|c|c|c|c|}
\hline SUM & 2.28571 & 2.73333 & 3.9 & 2.56667 & 3.5 & 5.16667 & 4.16667 & 5.5 & 7.5 & 5.5 & 7 & 8.5 & local \\
\hline & & & & & & & & & & & & & weight \\
\hline \multirow[t]{4}{*}{ AVG } & 0.4375 & 0.36585 & 0.25641 & 0.19481 & 0.28571 & 0.29032 & 0.48 & 0.45455 & 0.4 & 0.45455 & 0.42857 & 0.41176 & 0.37167 \\
\hline & 0.29167 & 0.36585 & 0.51282 & 0.38961 & 0.28571 & 0.19355 & 0.12 & 0.18182 & 0.2 & 0.27273 & 0.28571 & 0.29412 & 0.2828 \\
\hline & 0.14583 & 0.14634 & 0.12821 & 0.25974 & 0.28571 & 0.3871 & 0.24 & 0.18182 & 0.13333 & 0.09091 & 0.14286 & 0.17647 & 0.19319 \\
\hline & 0.125 & 0.12195 & 0.10256 & 0.15584 & 0.14286 & 0.12903 & 0.16 & 0.18182 & 0.26667 & 0.18182 & 0.14286 & 0.11765 & 0.15234 \\
\hline
\end{tabular}

Similarly, the inner dependence weight is calculated by above procedure for remaining main factors. The inter dependent weights are calculated by multiplying dependence matrix of factor with the local weight of factor. Calculated local and global weight of main and sub factors are shown in table 7.

Table VIII: Calculated local and global weight of main and sub factors

\begin{tabular}{|c|c|c|c|}
\hline Main factors & Sub factors & $\begin{array}{l}\text { Local } \\
\text { weight }\end{array}$ & $\begin{array}{l}\text { Global } \\
\text { weight }\end{array}$ \\
\hline \multirow{4}{*}{$\begin{array}{l}\text { Influence on } \\
\text { land } \\
(0.272)\end{array}$} & Area of top soil (AT) & 0.289447 & 0.152249 \\
\hline & $\begin{array}{l}\text { Plants and wild life } \\
\text { (PW) }\end{array}$ & 0.272282 & 0.14322 \\
\hline & $\begin{array}{l}\text { Roads and residence } \\
\text { (RR) }\end{array}$ & 0.253121 & 0.133142 \\
\hline & Earthquake (EQ) & 0.18515 & 0.097389 \\
\hline \multirow{5}{*}{$\begin{array}{l}\text { Influence on } \\
\text { water } \\
(0.303)\end{array}$} & $\begin{array}{l}\text { Chemical explosive } \\
\text { (CE) }\end{array}$ & 0.275993 & 0.136893 \\
\hline & $\begin{array}{l}\text { Acid mine drainage } \\
(\mathrm{AMD})\end{array}$ & 0.263551 & 0.130721 \\
\hline & $\begin{array}{l}\text { Change in ground } \\
\text { level (CGL) }\end{array}$ & 0.212209 & 0.105255 \\
\hline & Water habitat (WH) & 0.113992 & 0.05654 \\
\hline & $\begin{array}{l}\text { Nitrates release into } \\
\text { water }(\mathrm{NRW})\end{array}$ & 0.134255 & 0.06659 \\
\hline \multirow{4}{*}{$\begin{array}{l}\text { Influence of } \\
\text { gases } \\
(0.153)\end{array}$} & $\begin{array}{l}\text { Greenhouse gases } \\
(\mathrm{GHG})\end{array}$ & 0.326779 & 0.130058 \\
\hline & $\begin{array}{l}\text { Coal bed methane } \\
(\mathrm{CBM})\end{array}$ & 0.284733 & 0.113324 \\
\hline & Seam gas (SG) & 0.177749 & 0.070744 \\
\hline & $\begin{array}{l}\text { Methane in fugitive } \\
\text { manner (MFM) }\end{array}$ & 0.210739 & 0.083874 \\
\hline \multirow{2}{*}{$\begin{array}{l}\text { Influence of } \\
\text { dust } \\
(0.193)\end{array}$} & $\begin{array}{l}\text { Hauling \& blasting } \\
(\mathrm{H} \& \mathrm{~B})\end{array}$ & 0.362814 & 0.130976 \\
\hline & $\begin{array}{l}\text { Aesthetic damage } \\
\text { (AD) }\end{array}$ & 0.3615 & 0.130501 \\
\hline
\end{tabular}

The activities involved in the mining industries are helpful to fulfill the customer needs and also for growth of country. But the availability of natural resources is drastically reduced. By the activities of mining industries, the environmental property and human health are affected. In this paper, the factors which are causing the effect and the substance which got affected are mentioned. The factors are structured using one of the MCDM tool is ANP. Using ANP (analytical network process), the factors are structured and calculated. Therefore the factors which are get majorly affected is decided based on the local and global weight calculated. If the calculated values are not in appropriate sequence to factor selected, then redesign the model or corrective actions are need to be taken. In this paper, based on our calculated weight it is observed that "influence on land" have highest weight among the main factors which is followed by "influence on water", "influence on gases", "influence on dust" and "truck and equipment". Among the sub factors area of top soil, plants and wildlife, roads and residence are belongs to influence on land. Then it is followed by chemical explosive, acid mine drainage which comes under 
influence on water. The mining industries must take corrective action to reduce the amount of factors that affecting the environment. The industries also have responsibility to prevent the environment. Some of the steps suggested preventing the environment like proper maintains of machines, proper utilization of chemicals etc., supervising the mining activities like blasting, digging, separation and filtration etc., proper disposal of industrial wastes.

\section{REFERENCES}

1. H.Jenkins and N.Yakovleva, "Corporate social responsibility in the mining industry: Exploring trends in social and environmental disclosure," Journal of cleaner production, 2006, Vol: 14(3-4), pp.271-284.

2. S.Kusi-Sarpong, C.Bai, J.Sarkis, and X.Wang, "Green supply chain practices evaluation in the mining industry using a joint rough sets and fuzzy TOPSIS methodology,” Resources Policy, 2015, Vol: 46, pp.86-100.

3. L.F.Silva, M.L.Oliveira, E.R.Neace, O'Keefe, J.M.Henke, and J.C.Hower, "Nanominerals and ultrafine particles in sublimates from the Ruth Mullins coal fire, Perry County, Eastern Kentucky, USA," International Journal of Coal Geology, 2011, vol:85(2), pp.237-245.

4. B.I.A.N Zhengfu, H.I.Inyang, J.L.Daniels, O.T.T.O.Frank, and S.Struthers, "Environmental issues from coal mining and their solutions," Mining Science and Technology (China), 2010, Vol: 20(2), pp.215-223.

5. Z.Bian, J.Dong, S.Lei, H.Leng, S.Mu and H.Wang, "The impact of disposal and treatment of coal mining wastes on environment and farmland," Environmental Geology, 2009, Vol: 58(3), pp.625-634

6. R.K.Tiwary, "Environmental impact of coal mining on water regime and its management. Water, Air, and Soil Pollution," 132(1-2), 2001 pp.185-199.

7. LL.Sloss "Environmental and other effects of coal mining and transport. IEA clean coal centre, 2017,” 978-92-9029-604-1.

8. Z.Ayağ, and R.G.Özdemir, "An intelligent approach to machine tool selection through fuzzy analytic network process," Journal of intelligent manufacturing, 2011, Vol: 22(2), pp.163-177.

9. C.Kahraman, T.Ertay and G.Büyüközkan, "A fuzzy optimization model for QFD planning process using analytic network approach," European Journal of Operational Research, 2006, Vol: 171(2), pp.390-411..

10. J.Razmi, H.Rafiei, and M.Hashemi, "Designing a decision support system to evaluate and select suppliers using fuzzy analytic network process," Computers \& Industrial Engineering, 2009, Vol: 57(4), pp.1282-1290.

11. I.Thornton, "Impacts of mining on the environment; some local, regional and global issues. Applied geochemistry," Vol:11(1-2), 1996, pp.355-361.

12. N.F Gray, "Environmental impact and remediation of acid mine drainage: a management problem," Environmental Geology, Vol:30(1-2), 1997, pp. 62-71.

13. S.Dudka, and D.C Adriano, "Environmental impacts of metal ore mining and processing: a review," Journal of environmental quality, Vol:26(3), 1997 ,pp.590-602.

\section{AUTHORS PROFILE}

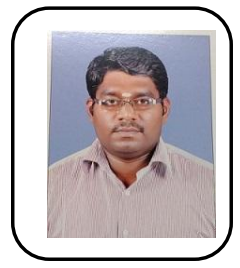

M.Ramaganesh obtained his Bachelor of Engineering in Mechanical Engineering from Arulmigu Kalasalingam College of Engineering, India in 2008. He finished his Master of Engineering in Industrial Engineering from Thiagarajar College of Engineering, India in 2015. He is currently taking up Doctor of Engineering with specialization in Industrial Engineering from Kalasalingam Academy of Research and Education, India. He is the member of Indian Society for Technical Education. His research interest includes Sustainability, Supply Chain Management, Environmental Management System and Corporate Social Responsibility.

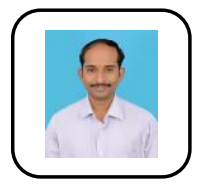

Dr.S.Bathrinath is an Associate Professor in the Department of Mechanical Engineering, Kalasalingam Academy of Research and Education, Krishnankoil, Tamilnadu, India. His current area of research includes multi-criteria decision making, scheduling \& optimization, soft computing and Artificial intelligence. He has published a number of papers in journal of national/international repute and presented a number of papers in various conferences/symposia in India and abroad. He is presently guiding a number of master/doctoral research scholars. Dr.S.Bathrinath is the corresponding author and can be contacted at: bathri@gmail.com

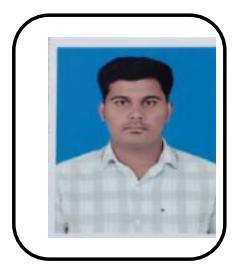

S.Devendran obtained his Bachelor of Technology in Mechanical Engineering from Kalasalingam Academy of Research and Education in 2019. His area of interest includes Production Planning and Control, Supply Chain Management and Environmental Management System.

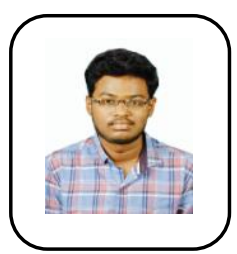

T.Hariharan obtained his Bachelor of Technology in Mechanical Engineering from Kalasalingam Academy of Research and Education in 2019. His research interest includes Industrial Engineering, Sustainability and Supply Chain Management.

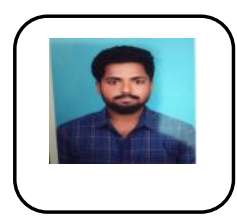

A.Hariharan obtained his Bachelor of Technology in Mechanical Engineering from Kalasalingam Academy of Research and Education in 2019. His research interest includes Sustainability and Supply Chain Management. 